\title{
KINERJA OIL SPILL DISPERSANT DALAM PROSES BIOREMEDIASI TANAH TERCEMAR MINYAK BUMI (STUDI KASUS TANAH TERCEMAR MINYAK BUMI LAPANGAN XYZ)
}

\section{PERFORMANCE OF OIL SPILL DISPERSANT IN BIOREMEDIATION PROCESS OF PETROLEUM CONTAMINATED SOIL (CASE STUDY OF PETROLEUM CONTAMINATED SOIL FROM XYZ FIELD)}

\author{
Imam Chanif ${ }^{1}$, Erliza Hambali ${ }^{1,2)}$, dan Mohamad Yani ${ }^{1{ }^{*}}$ \\ ${ }^{1)}$ Departemen Teknologi Industri Pertanian, Institut Pertanian Bogor, \\ Kampus Dramaga, Bogor 16680, Indonesia \\ ${ }^{2}$ Surfactant and Bioenergy Research Center, LPPM, Institut Pertanian Bogor, \\ Kampus Baranangsiang, Bogor 16143, Indonesia \\ Email: f226yani@gmail.commoh.yani@ipb.ac.id
}

Makalah: Diterima 21 Agustus 2017; Diperbaiki 18 November 2017; Disetujui 12 Desember 2017

\begin{abstract}
Oil spill dispersant (OSD) is a surfactant product that serves as dispersant. OSD has been widely used and proven to be effective in oil spills both in the sea and in the land. The OSD-SBRC (Surfactant and Bioenergy Research Center) IPB was produced from palm oil, while the commercial product of OSD S200 was made from LAS (Linear Alkyl Benzene Sulfonate) based from petroleum. Application of OSD in bioremediation testing occurred on petroleum contaminated soil from the field with initial total petroleum hydrocarbon of 6-10\%. The treatment of dispersant to oil ratio (DOR) was at 0.5:1 and 1:1. The contaminated soil was added with Pseudomonas aeruginosa and fertilizers (Urea and SP36) to support bacterial growth. The environmental soil conditions during the bioremediation process were observed as $\mathrm{pH}$, moisture content, and temperature. The OSD performance in bioremediation process was measured as TPH (Total Petroleum Hydrocarbon) and TPC (Total Plate Count). The results showed that $\mathrm{pH}$, moisture content and temperature levels were at optimum condition for bacterial growth to optimally degrade the hydrocarbon. The result of TPC value showed that treatment with the addition of OSD S200 caused inhibition of microbial growth P. aeruginosa bacteria. The TPH measurements showed that treatment with OSD SBRC with DOR (0.5:1) was able to degrade hydrocarbons up to $89.62 \%$. The bioremediation process using OSD-SBRC was better than OSD S200.
\end{abstract}

Keywords: bioremediation, hydrocarbon, OSD, surfactant

\section{ABSTRAK}

Oil spill dispersant (OSD) merupakan produk surfaktan yang berfungsi sebagai dispersant. OSD banyak digunakan untuk menghilangkan minyak di laut maupun di tanah. Produk OSD SBRC (Pusat Penelitian Surfaktan dan Bioenergi) IPB berbahan dasar surfaktan minyak sawit, sedangkan OSD komersil S200 berasal dari LAS (liniear alkylbenzene sulfonat) yang berbahan dasar dari minyak bumi. Aplikasi OSD dalam proses bioremediasi dilakukan pengujian pada tanah tercemar minyak bumi yang berasal dari lapangan dengan nilai TPH (total petroleum hydrocarbon) sebesar 6-10\%. Perlakuan penelitian menggunakan DOR OSD 0,5:1 dan 1:1). Tanah terkontaminasi ditambahkan bakteri Pseudomonas aeruginosa dan nutrisi (urea dan SP36) untuk mendukung pertumbuhan bakteri. Pengamatan kondisi lingkungan selama proses bioremediasi dilakukan dengan mengukur suhu, $\mathrm{pH}$ dan kadar air yang ada didalam tanah. Uji kinerja OSD dalam bioremediasi dilakukan pengukuran TPH dan TPC. Hasil pengamatan suhu, $\mathrm{pH}$, dan kadar air menunjukkan kondisi yang optimum untuk pertumbuhan bakteri dalam mendegradasi hidrokarbon. Hasil TPC menunjukkan perlakuan dengan penambahan OSD S200 menyebabkan penghambatan pertumbuhan bakteri $P$. aeruginosa. Hasil pengukuran TPH menunjukkan OSD SBRC dengan DOR (0,5:1) dapat mendegradasi hidrokarbon 89,62\%. Hasil bioremediasi pada penelitian ini penggunaan OSD SBRC lebih baik dibandingkan OSD S200.

Kata kunci: bioremediasi, hidrokarbon, OSD, surfaktan

\section{PENDAHULUAN}

Pencemaran tanah oleh minyak disebabkan melalui dua cara diantaranya dari tumpahan minyak ataupun minyak yang sudah terkubur dalam tanah itu sendiri (Helmy et al., 2015). Pencemaran minyak ini menyebabkan kerusakan lingkungan yang mempengaruhi ekosistem khususnya ekosistem di dalam tanah. Menurut Khalilova (2015) dampak dari pencemaran minyak terhadap tanah menyebabkan kecilnya jumlah mineral yang tersedia di dalam tanah. Hal tersebut menyebabkan ekosistem yang ada di dalam tanah menjadi terganggu, sehingga jumlah organisme yang dapat menyuburkan tanah menjadi hilang. Penanggulangan yang dilakukan untuk menghilangkan pencemar minyak bumi salah 
satunya dengan cara biologi. Cara biologi atau biasa disebut bioremediasi terbukti efektif dan murah, selain itu juga tidak menyebabkan pencemaran lain pada lingkungan.

Bioremediasi merupakan suatu teknologi untuk mengurangi atau menghilangkan kontaminan yang berbahaya menjadi tidak berbahaya dengan menggunakan mikroorganisme. Melalui proses mineralisasi, mikoorganisme akan mengubah kontaminan yang berbahaya menjadi bahan yang tidak berbahaya. Proses tersebut yaitu mengubah kontaminan dengan struktur kimia organik yang komplek menjadi struktur kimia anorganik yang tidak komplek dan mudah terdegradasi (Adams et al., 2015). Teknik bioremediasi untuk tanah tercemar minyak bumi berjalan tidak sempurna dikarenakan minyak terjerat oleh partikel tanah, sehingga akan menurunkan kecepatan biodegradasi oleh bakteri (Allen et al., 1998). Oleh karena itu perlu adanya pengembangan terkait dengan teknologi dalam teknik bioremediasi. Salah satunya dengan memanfaatkan agen pendispersi seperti oil spill dispersant (OSD).

OSD merupakan produk yang berbahan utama surfaktan. Surfaktan akan menurunkan tegangan permukaan antara minyak dan air. OSD sudah banyak dikembangkan sejak tahun 1960 sampai saat ini. Perkembangan OSD saat ini telah berfokus kepada bahan yang bersifat tidak toksik dan biodegradable. Salah satu produk OSD yang sudah banyak digunakan sebagai agen bioremediasi yaitu OSD S200. Bahan baku utama surfaktan dalam OSD S200 yaitu LAS. Surfaktan LAS merupakan surfaktan yang berbahan dasar minyak bumi. Surfaktan ini banyak digunakan pada produk deterjen. Hasil penelitian Charlena et al. (2011) menunjukkan penambahan surfaktan LAS dengan konsentrasi yang rendah mampu meningkatkan kelarutan hidrokarbon dalam air.

Saat ini SBRC-IPB juga telah berhasil mengembangkan produk OSD yang berasal dari surfaktan yang dihasilkan dari minyak sawit. Hasil penelitian yang dilakukan oleh Adlina et al. (2017) terkait dengan kinerja OSD SBRC yang dikombinasikan dengan Pseudomonas aeruginosa pada tanah simulasi tercemar hidrokarbon sebesar 6\% menunjukkan pemberian OSD SBRC sudah dapat menurunkan TPH sampai $84,32 \%$ selama 40 hari. Berdasarkan potensi dari produk OSD SBRC yang dihasilkan maka perlu dilakukan penelitian lanjutan yang bertujuan untuk menguji kinerja OSD SBRC yang akan dibandingkan dengan OSD yang sudah komersil. OSD S200 dipilih sebagai OSD pembanding karena OSD ini sudah banyak digunakan dalam proses bioremediasi sejak tahun 1994 hingga saat ini. Tujuan dari penelitian ini yaitu untuk mengevaluasi kemampuan OSD SBRC dan OSD S200 dalam proses bioremediasi tanah tercemar minyak bumi dari lapangan pengeboran minyak.

\section{BAHAN DAN METODE}

\section{Persiapan Inokulum Bakteri (Starter)}

Bakteri yang digunakan pada penelitian ini yakni Pseuodomonas aeruginosa IPBCC.b11662. Bakteri diperbanyak terlebih dahulu pada media nutrient broth, sebelum digunakan bakteri diadaptasi pada media minimum yang mengandung $10 \%$ hidrokarbon. Bakteri diinokulasikan pada media adaptasi sebesar 10\%. Bakteri diinkubasi pada waterbath shaker dengan kecepatan $120 \mathrm{rpm}$ dengan suhu $37^{\circ} \mathrm{C}$ selama 5 hari (Zhang et al., 2005). Bakteri yang diadaptasi ini selanjutnya digunakan dalam proses bioremediasi.

\section{Aplikasi Bioremediasi}

Tanah yang digunakan dalam penelitian ini berasal dari lapangan pengeboran minyak dari Lapangan XYZ. Tanah tercemar minyak dilakukan analisis awal berupa TPH untuk menentukan perlakuan dan persiapan tanah. Penelitian bioremediasi dilakukan pada box berukuran 39 x 31 $\mathrm{x} 13 \mathrm{~cm}^{3}$. Campuran tanah dan pasir dengan perbandingan 4:2. Tanah ditambahkan bakteri sebanyak $10 \%$ (v/w) dan nutrisi untuk pertumbuhan bakteri dengan rasio $\mathrm{C}: \mathrm{N}: \mathrm{P}$ (100:10:1). Perlakuan OSD disajikan pada Tabel 1. OSD yang digunakan pada penelitian ini yaitu OSD SBRC dan OSD S200.

Tabel 1. Komposisi masing-masing perlakuan bioremediasi

\begin{tabular}{cccc}
\hline Perlakuan & $\begin{array}{c}\text { Tanah } \\
\text { (Kg) }\end{array}$ & OSD & $\begin{array}{c}\text { Dispersant to oil } \\
\text { ratio }(\text { DOR) }\end{array}$ \\
\hline P0 & 6 & - & - \\
P1 & 6 & SBRC & $0,5: 1$ \\
P2 & 6 & SBRC & $1: 1$ \\
P3 & 6 & S200 & $0,5: 1$ \\
P4 & 6 & S200 & $1: 1$ \\
\hline
\end{tabular}

*Keterangan: DOR (Dispersant to Oil ratio)

\section{Pengamatan Suhu, Kadar Air dan pH}

Pengamatan kondisi lingkungan berupa suhu, kadar air dan $\mathrm{pH}$ dilakukan setiap 1 minggu sekali untuk mengontrol kondisi optimum selama proses bioremediasi. Kondisi yang sesuai akan membuat proses bioremediasi berjalan secara optimum. Metode yang digunakan dalam pengukuran kadar air ini yaitu dengan cara gravimetri. Sedangkan pengukuran suhu tanah dilakukan dengan menggunakan alat termometer. Pengukuran $\mathrm{pH}$ dilakukan berdasarkan standar SNI 06-6989.11-2004.

\section{Pengamatan Pertumbuhan Populasi Bakteri}

Pengukuran TPC ini dilakukan dengan menumbuhkan bakteri ke dalam medium, sehingga mikroba tersebut akan berkembang biak dan membentuk koloni. Koloni tersebut yang kemudian dihitung. Pengukuran TPC ini berdasarkan metode APHA, 9215C. Pengukuran TPC dilakukan dua 
minggu sekali untuk melihat perkembangan dari bakteri tersebut.

\section{Pengamatan Total Petroleum Hydrocarbon}

Pengukuran hasil pengujian bioremediasi dilakukan dengan mengukur TPH yang ada di dalam tanah. Pengukuran TPH dilakukan selama 6 minggu dengan intensitas pengukuran setiap 2 minggu sekali. Pengukuran TPH merupakan parameter hasil bioremediasi yang paling penting dalam proses bioremediasi. Pengukuran TPH dilakukan dengan cara gravimetri dengan metode USEPA 1664 (USEPA, 1998). Proses pengukuran TPH ini dilakukan terhadap $10 \mathrm{~g}$ sampel tanah yang akan diekstrak dengan menggunakan pelarut n-heksan sebanyak $100 \mathrm{~mL}$. Proses ekstraksi dilakukan selama 6 jam dengan suhu $70^{\circ} \mathrm{C}$. Setelah proses ekstraksi selesai selanjutnya dilakukan evaporasi dengan rotary evaporator. Kemudian dilakukan pemanasan selama 45 menit dengan suhu $70^{\circ} \mathrm{C}$, dan didinginkan dengan desikator dan ditimbang. Berat yang didapat merupakan berat gemuk atau TOG (total oil and grease), sehingga untuk menghilangkan senyawa polar ditambahkan silika gel serta n-heksana. Setelah itu dilakukan evaporasi kembali dan penimbangan untuk mendapatkan hasil TPH.

\section{Analisis Data}

Data yang diperoleh selanjutnya dianalisis dengan menggunakan analisis ragam (ANOVA) ataupun dengan analisis secara deskriptif. Apabila pada analisis ragam didapatkan pengaruh nyata pada perlakuan, maka dilanjutkan analisis dengan menggunakan Tukey's test pada taraf kepercayaan $95 \%$.

\section{HASIL DAN PEMBAHASAN}

\section{Perubahan Suhu Kadar Air dan pH pada Proses Bioremediasi}

Suhu dapat mempengaruhi tingkat degradasi dari hidrokarbon, karena jika suhu yang terlalu rendah akan meningkatkan viskositas dari minyak yang menyebabkan volatilitas dari alkana rantai pendek akan menurun sehingga akan lebih sulit untuk didegradasi (Retno dan Mulyana, 2013).
Hasil pengukuran suhu selama proses bioremediasi berkisar antara $24-27^{\circ} \mathrm{C}$ (Gambar 1). Peningkatan suhu menunjukkan bahwa terdapat aktifitas mikroorganisme. Kondisi suhu yang optimal akan membuat pertumbuhan mikroorganisme optimal, sehingga proses degradasi hidrokarbon akan optimal. Menurut hasil penelitian dari Sari et al. (2015) kondisi optimum untuk pertumbuhan mikrooganisme yaitu antara $20-40^{\circ} \mathrm{C}$.

Penurunan TPH yang terjadi akibat aktifitas mikrooganisme ini tidak diiringi dengan adanya peningkatan suhu secara signifikan, karena dimungkinkan aktifitas eksoterm yang dilakukan oleh mikroorganisme tidak cukup untuk meningkatkan suhu di dalam tanah. Kondisi tersebut dapat dilihat pada minggu ke-2, dimana terdapat penurunan TPH yang signifikan tetapi suhu tanah yang terukur tidak berbeda jauh dengan suhu lingkungan pada saat proses bioremediasi. Kondisi tersebut diperkuat dengan adanya penurunan populasi mikroorganisme pada minggu ke-2, karena adanya proses adaptasi yang dilakukan oleh mikroorganisme. Jumlah populasi mikroorganisme yang mengalami penurunan menyebabkan aktifitas biodegradasi hidrokarbon tidak cukup untuk meningkatkan suhu yang ada di dalam tanah. Hal ini sesuai dengan hasil penelitian yang dilakukan oleh Putri et al. (2013) bahwa penurunan TPH yang disebabkan adanya aktfitas mikroorgasnime Bacillus subtilis dalam mendegradasi hidrokarbon tidak cukup untuk meningkatkan suhu tanah pada saat proses bioremediasi.

Kondisi lingkungan lain yang perlu diperhatikan yaitu tingkat keasaman dari tanah atau $\mathrm{pH}$. Pengukuran $\mathrm{pH}$ dilakukan setiap satu minggu sekali untuk mengontrol $\mathrm{pH}$ yang optimal untuk pertumbuhan bakteri. Pada hasil pengukuran $\mathrm{pH}$ (Gambar 2) menunjukkan $\mathrm{pH}$ awal saat diberikan perlakuan masih normal, dimana antara $\mathrm{pH} 7,45$ 8,14 . Pada pengamatan setelah perlakuan selama 2 minggu menunjukkan adanya peningkatan $\mathrm{pH}$ menjadi 8,79-8,87, hal ini dikarenakan adanya penambahan pupuk anorganik berupa urea dan SP36 pada awal untuk mendukung pertumbuhan mikroorganisme.

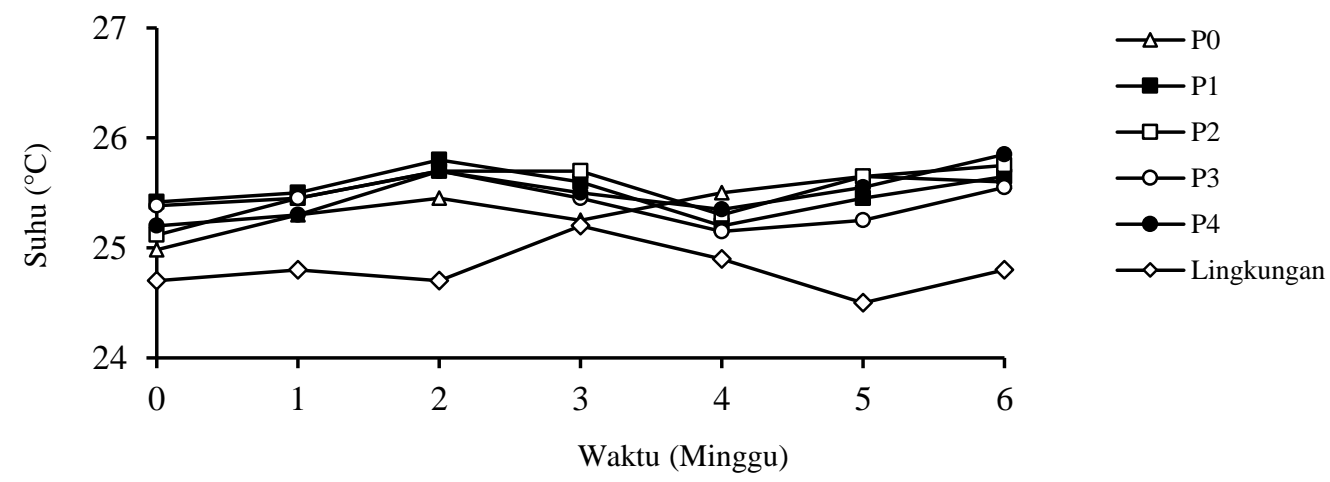

Gambar 1. Pengaruh perubahan suhu $\left({ }^{\circ} \mathrm{C}\right)$ selama proses bioremediasi 
Hasil pH yang terukur tersebut masih dalam kondisi bakteri masih dapat tumbuh. Hasil penelitian yang dilakukan oleh Kumar dan Philip (2006) bahwa bakteri dan jamur yang digunakan dalam proses bioremediasi masih dapat mendegradasi hidrokarbon hingga $\mathrm{pH}$ 10. Selain itu adanya kenaikan $\mathrm{pH}$ ini disebabkan karena adanya aktifitas mikroorganisme dalam mendegradasi hidrokarbon yang mengakibatkan peningkatan $\mathrm{pH}$.

Aktifitas mikroorganisme yang menyebabkan peningkatan $\mathrm{pH}$ saat awal proses bioremediasi ini dimungkinkan karena bakteri memiliki kemampuan dalam toleransi dengan cara pompa hidrogen. Mekanisme yang terjadi yaitu dengan cara menukar kation $\mathrm{K}^{+}$yang berada dalam sel dengan $\mathrm{H}^{+}$yang berada pada lingkungan (Retno dan Mulyana, 2013). Saat kondisi pH mencapai 8,87 dilakukan penanggulangan untuk menurunkan $\mathrm{pH}$, karena dikhawatirkan jika $\mathrm{pH}$ terlalu basa akan menyebabkan proses biodegradasi tidak maksimal. Penambahan asam yaitu $\mathrm{H}_{2} \mathrm{SO}_{4} 5 \%$ menurunkan $\mathrm{pH}$ pada kondisi optimum. Pada pengamatan minggu ke 3 pH tanah kembali pada kondisi optimum yaitu 7,91 - 8,15. Menurut Vidali (2001) bahwa pH yang sesuai untuk pertumbuhan bakteri yaitu 6,5 - 8 . Penurunan $\mathrm{pH}$ pada minggu ke 3 sampai ke 6 secara berturut karena aktifitas mikroorganisme dalam proses bioremediasi yang menghasilkan asam-asam organik. Menurut Pawar (2015) penurunan pH saat proses bioremediasi diakibatkan adanya produksi asam-asam organik dari hasil proses biodegradasi hidrokarbon oleh mikroorganisme.
Kadar air merupakan indikator lingkungan yang memiliki peranan besar dalam proses bioremediasi. Air sangat berpengaruh terhadap aktivitas mikroorganisme, hal ini karena sebagian besar sel dari mikroorganisme mengandung air. Ketersediaan air dalam tanah harus selalu dijaga supaya aktifitas mikroorganisme dalam mendegradasi hidrokarbon dapat maksimal. Fungsi air di dalam tanah yaitu sebagai media pembawa nutrisi ke dalam sel bakteri dan media untuk perpindahan bakteri dari satu tempat ke tempat lain (Yadav dan Hassanizadeh, 2011).

Kadar air yang terukur pada proses bioremediasi selama 6 minggu yaitu antara 18-24\% (Gambar 3). Kondisi kadar air di dalam tanah dipertahankan minimum $20 \%$ untuk menunjang pertumbuhan dari mikroorganisme. Jika kadar air di dalam tanah kurang akan menyebabkan pertumbuhan dari mikroorganisme itu sendiri menjadi terhambat dan juga proses biodegradasi akan terhambat. Jika terlalu tinggi kadar air dalam tanah akan menyebabkan ketersedian oksigen dalam tanah menjadi kurang, sehingga proses biodegradasi senyawa alifatik secara aerob tidak maksimal. Menurut Yadav dan Hassanizadeh (2011) kadar air yang cukup akan mempermudah bakteri masuk ke dalam polutan yanga berada di dalam tanah. Kondisi ini akan lebih efektif jika terdapat surfaktan yang dapat mendispersikan hidrokarbon ke dalam air tanah. Hidrokarbon akan lebih mudah terdegradasi oleh mikroorganisme.

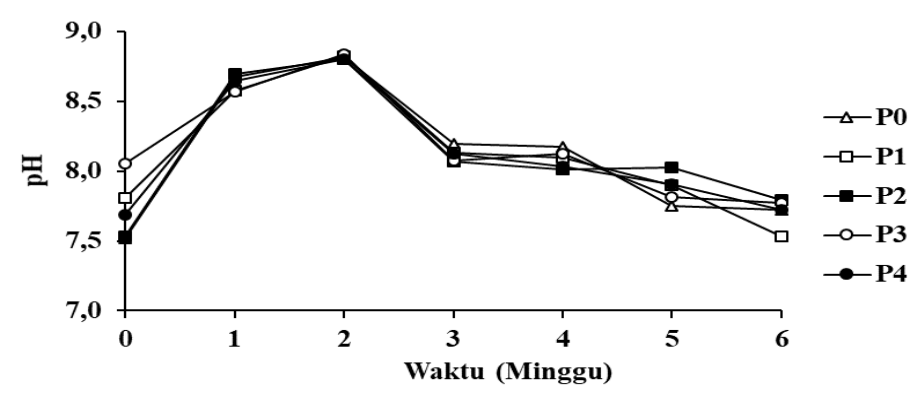

Gambar 2. Pengaruh perubahan $\mathrm{pH}$ selama proses bioremediasi

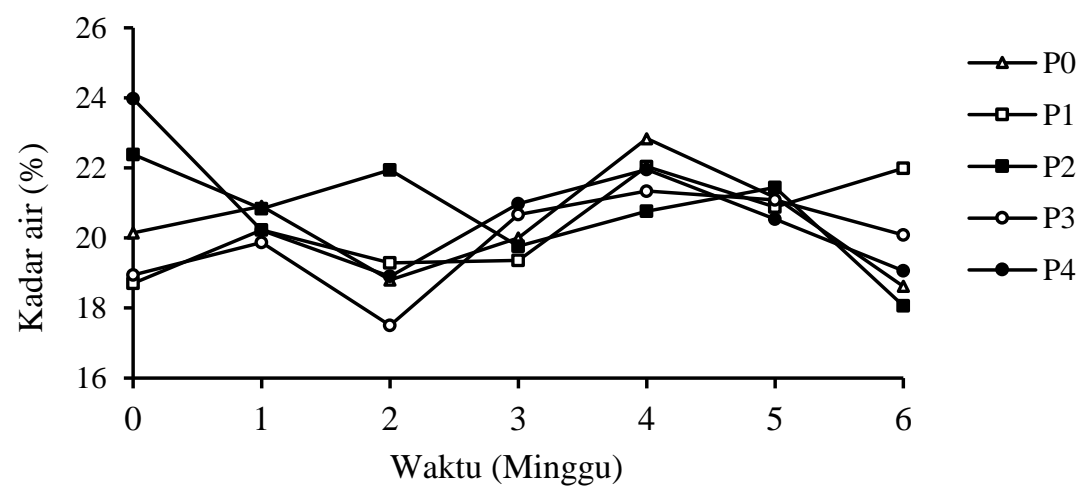

Gambar 3. Pengaruh perubahan kadar air (\%) selama proses bioremediasi 


\section{Perubahan Populasi Bakteri}

Populasi bakteri merupakan indikator bagaimana proses bioremediasi yang dilakukan tersebut dapat berjalan dan berapa jumlah bakteri yang berperan dalam proses bioremediasi. Hasil pengukuran TPC pada penelitian ini yaitu $1 \times 10^{6}$ $(\mathrm{SPK} / \mathrm{g})$ sampai dengan $1 \times 10^{8} \quad(\mathrm{SPK} / \mathrm{g})$. Setiap mikroorganisme memiliki lama siklus hidup yang berbeda-beda. Bakteri $P$. aeruginosa memiliki waktu pertumbuhan eksponensial selama 4-20 jam sedangkan fase stasioner yaitu 20-72 jam (Adlina $e t$ al., 2017).

Hasil pengukuran TPC minggu ke-2 (Gambar 4) menunjukkan penurunan pada semua perlakuan. Hal ini karena bakteri ataupun mikroba masih mengalami adaptasi pada lingkungan tersebut. TPH awal yang tinggi pada penelitian ini juga berpotensi menyebabkan penurunan populasi bakteri pada minggu ke 2. Perlakuan dengan penambahan OSD S200 pada pengamatan minggu pertama dan kedua merupakan populasi bakteri yang terendah dibandingkan dengan kontrol maupun dengan perlakuan menggunakan OSD SBRC. Pada pengamatan minggu ke-4 kedua perlakuan yaitu P3 dan P4 mengalami kenaikan jumlah populasi dan pada akhir pengukuran pada minggu ke 6 jumlah populasi tidak berbeda jauh dengan perlakuan lain. Hal ini menunjukkan bahwa pada perlakuan menggunakan OSD S200 mengalami penghambatan pertumbuhan mikroba pada awal minggu saat pengujian bioremediasi. Hasil penelitian ini diperkuat oleh penelitian Murado et al. (2004) bahwa jumlah bakteri (SPK/g) mengalami penurunan jumlah setelah adanya pemberian OSD S200. Hasil analisis DNA yang dilakukan pada penelitian tersebut menunjukkan bahwa keragaman DNA pada perlakuan OSD S200 lebih rendah dibandingkan dengan control.

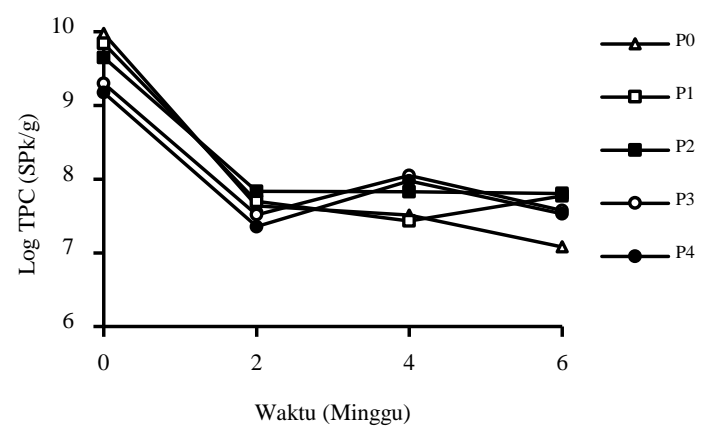

Gambar 4. Pengaruh perubahan populasi bakteri selama proses bioremediasi

Proses bioremediasi yang memanfaatkan bakteri sebagai pendegradasi hidrokarbon atau biasa disebut bakteri hidrokarbonalistik. Secara umum terdapat 3 cara transpor hidrokarbon dalam sel bakteri, yaitu (1) interaksi sel dengan hidrokarbon yang terlarut dalam fase air, (2) kontak langsung dengan (perlekatan) sel dengan permukaan tetesan hidrokarbon, dan (3) interaksi sel dengan tetesan hidrokarbon yang teremulsi atau tersolubilisasi oleh bakteri (Lumbanraja, 2014). Pada penelitian ini pemberian surfaktan bertujuan agar hidrokarbon teremulsi, sehingga transpor hidrokarbon di dalam sel bakteri lebih mudah.

Hasil pengukuran TPC (Gambar 5) menunjukkan semakin tinggi konsentrasi OSD yang diberikan semakin rendah hasil TPC yang didapatkan. Hal ini sama dengan penelitian Cueva et al. (2016) yang menunjukkan semakin tinggi jumlah surfaktan tween 80 yang diberikan akan semakin rendah jumlah populasi bakteri. OSD yang diberikan dalam proses bioremediasi ini dimungkinkan dapat menghambat pertumbuhan dari bakteri. Penghambatan pertumbuhan bakteri akan menyebabkan proses biodegradasi juga terhambat. Bakteri pada dasarnya sudah dapat menghasilkan biosurfaktan untuk membantu dalam proses bioremediasi. Bakteri $P$. aeruginosa yang digunakan dapat menghasilkan biosurfaktan Rhamnolipids (Urum et al., 2004). Surfaktan dalam proses bioremediasi menurut Mulligan et al. (2001) memiliki manfaat dalam membantu mikroorganisme dalam mendegradasi hidrokarbon dan juga dapat mendispersikan polutan yang ada dalam air tanah. Surfaktan ini memiliki banyak manfaat selain dalam mempercepat proses biodegradasi juga dapat mendispersikan polutan dalam air tanah. Syarat OSD yang digunakan untuk proses bioremediasi yaitu tidak toksik dan biodegradable, hal ini bertujuan agar tidak timbul cemaran lain akibat pemberian OSD dalam proses bioremediasi.

Salah satu bahan dasar surfaktan dalam OSD S200 ialah LAS (liniear alkylbenzene sulfonate). Surfaktan tersebut merupakan surfaktan yang menggantikan ABS (alkyl benzene sulfonate) yang pada awalnya bersifat toksik. Surfaktan tersebut merupakan surfaktan yang banyak digunakan dalam deterjen. Surfaktan LAS merupakan surfaktan yang bersifat biodegradable, akan tetapi menurut Budiawan et al. (2009) menunjukkan bahwa gugus benzene, asam benzoat, hidroksil dan karbon alifatik tidak bisa terdegradasi oleh mikroorganisme. Hal tersebut menunjukkan bahwa surfaktan tersebut masih memiliki beberapa gugus toksik yang dapat mencemari lingkungan.

Mekanisme bakteri dapat mendegradasi hidrokarbon yaitu pertama bakteri akan menghasilkan enzim sesuai dengan polutan yang akan didegradasi. Enzim tersebut dihasilkan selama proses pengayaan dari bakteri itu sendiri (Ravindra et al., 2014). Mikroorganisme akan mengubah bahan toksik tersebut menjadi bahan yang tidak toksik dengan beberapa mekanisme. Enzim yang dikeluarkan setiap mikroorgansime tidak sama, tergantung dari jenis bakteri dan polutan yang akan didegradasi oleh bakteri tersebut. Proses biodegradasi hidrokarbon dengan menggunakan bakteri dari genus Pseudomonas akan berbeda 
dengan genus lain seperti Bacillus. Proses biodegradasi hidrokarbon oleh $P$. aeruginosa menurut Lumbanraja (2014) terbagi menjadi dua tergantung dari senyawa yang akan didegradasi. Biodegradasi senyawa hidrokarbon alifatik dengan bakteri Pseudomonas dilakukan dengan cara aerobik. Tanpa adanya oksigen proses biodegradasi tidak akan terjadi. Proses degradasi yang dilakukan bakteri meliputi oksidasi molekuler $\left(\mathrm{O}_{2}\right)$ sebagai sumber reaktan dan penggabungan antara satu atom oksigen ke dalam hidrokarbon teroksidasi. Sehingga beberapa senyawa akan menguap dan terakumulasi di udara.

Proses biodegradasi bakteri $P$. aeruginosa untuk senyawa hidrokarbon aromatik berbeda dengan senyawa alifatik. Proses biodegradasi senyawa aromatik akan melibatkan enzim oksidase yang melibatkan plasmid dan kromosom gen $\mathrm{xy} / \mathrm{E}$ dari bakteri $P$. aeruginosa. Enzim oksidase yang diproduksi dalam gen tersebut yaitu enzim katekol 2,3-dioksigenase. Proses biodegradasi yang dilakukan bakteri diawali dengan pembentukan protocatechuate atau catecol atau senyawa yang secara struktur berhubungan dengan senyawa ini. Selanjutnya senyawa tersebut akan didegradasi oleh enzim katekol 2,3-dioksigenase menjadi senyawa yang dapat masuk ke dalam siklus Krebs (siklus asam sitrat) yaitu suksinat, asetil KoA, dan purivat (Lumbanraja, 2014). Berdasarkan kedua proses dalam biodegradasi yang dilakukan oleh bakteri $P$. aeruginosa akan menghasilkan senyawa yang lebih mudah untuk didegradasi oleh mikroorganisme lain. Karena dalam proses bioremediasi sendiri tidak hanya melibatkan satu jenis mikroba, akan tetapi berbagai jenis mikroba.

\section{Total Petroleum Hydrocarbon (TPH)}

Aplikasi bioremediasi yang dilakukan mengacu pada Keputusan Menteri Negara Lingkungan Hidup No 123 Tahun 2003 tentang tata cara dan persyaratan teknik pengelolaan minyak bumi dan tanah terkontaminasi minyak bumi secara biologis. Pengukuran dilakukan dengan cara mengukur kondisi awal dari TPH yang tidak lebih dari $15 \%$, sedangkan hasil akhir dari pengolahan bioremediasi yaitu 1\% (Kemen LH, 2003). Nilai awal TPH yang terukur dari tanah terkontaminasi minyak bumi yaitu 11-13\%. Nilai awal TPH yang terukur dari ke-5 perlakuan tidak sama, hal ini karena tanah yang digunakan merupakan tanah terkontaminasi minyak yang diambil dari lapangan pengeboran minyak bumi. Kondisi lapangan yang memiliki banyak faktor penyebab yang antara lain jumlah minyak yang mencemari tanah yang tidak merata menyebabkan kondisi TPH awal dari tanah berbeda-beda. Pada proses persiapan tanah sudah dilakukan penyaringan dan pengadukan untuk mendapatkan hasil TPH yang sama setiap perlakuan, akan tetapi tidak terjadi perbedaan kandungan TPH pada awal.
Hasil TPH terendah setelah 6 minggu proses bioremediasi pada penelitian ini yaitu $\mathrm{P} 1=$ $1,35 \%$. Perlakuan lain masing-masing $\mathrm{P} 2=1,95 \%$; $\mathrm{P} 3=2,79 \%$ dan $\mathrm{P} 4=2,78 \%$, sedangkan $\mathrm{P} 0=3,34 \%$ (Gambar 5). Berdasarkan hasil TPH menunjukkan perlakuan OSD SBRC lebih rendah dibandingkan perlakuan OSD S200. Hasil pengukuran TPH pada semua perlakuan pada minggu ke-2 mengalami penurunan secara tajam. Hal ini diduga karena bakteri $P$. aeruginosa langsung memanfaatkan sumber hidrokarbon tersebut dalam metabolismenya. Penambahan OSD yang berbahan baku utama surfaktan akan mempercepat proses bioremediasi, karena akan menurunkan tegangan permukaan antara minyak dan air dengan membentuk mikroemulsi, sehingga proses biodegradasi akan lebih efektif. Selain itu juga bakteri akan lebih mudah dalam merombak senyawa hidrokarbon menjadi senyawa $\mathrm{CO}_{2}, \mathrm{H}_{2} \mathrm{O}$ dan asam-asam organik yang lebih sederhana (Charlena et al., 2011).

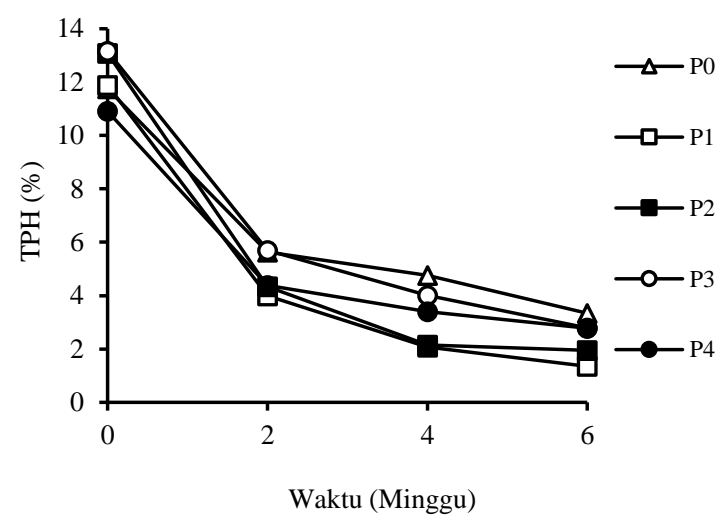

Gambar 5. Pengaruh perubahan TPH selama proses bioremediasi

Hasil analisis ANOVA degradasi TPH pada minggu ke-6 menunjukkan perlakuan jenis OSD dan DOR OSD berpengaruh terhadap penurunan TPH (P>0,01) (Gambar 6). Hasil analisis lanjut Tukkey's test dengan taraf kesalahan sebesar 0,05 menunjukkan perlakuan P1 yaitu OSD SBRC (DOR $0,5: 1)$ berbeda nyata dengan perlakuan kontrol (tanpa penambahan OSD), sedangkan dengan perlakuan lain tidak berbeda nyata (Gambar 6). Hasil tersebut menunjukkan bahwa perbedaan DOR dan jenis OSD yang ditambahkan tidak berpengaruh terhadap penurunan TPH secara statistik. Hasil degradasi TPH tertinggi pada penelitian ini yaitu pada perlakuan OSD SBRC pada P1 $(89,62)$, sedangkan perlakuan lain pada P2 yaitu $81,11 \%$. Perlakuan dengan penambahan OSD S200 pada perlakuan P3 dan P4 menunjukkan hasil penurunan yaitu 75,29\% dan 75,09\%. Perlakuan kontrol (tanpa OSD) yaitu $71,13 \%$.

Penambahan OSD pada penelitian ini bertujuan untuk melepaskan minyak yang terjerat oleh matriks tanah. Menurut Thapa et al. (2012) bahwa penambahan pembersih yang memiliki bahan 
surfaktan dapat meningkatkan ketersediaan minyak dalam mikroba dan mempercepat proses biodegradasi minyak. Hal ini karena surfaktan memiliki kemampuan dalam menurunkan tegangan permukaan minyak dan air sehingga minyak akan larut dalam air dan mikroba akan lebih mudah dalam memanfaatkan hidrokarbon sebagai sumber karbon dalam metabolismenya. Surfaktan yang ditambahkan dalam proses bioremediasi ini juga akan dimanfaatkan oleh bakteri $P$. aeruginosa sebagai sumber karbon. Hal tersebut karena komponen surfaktan yang mudah didegradasi oleh mikroorganisme, sehingga surfaktan yang ditambahkan juga akan dimanfaatkan sebagai sumber karbon.

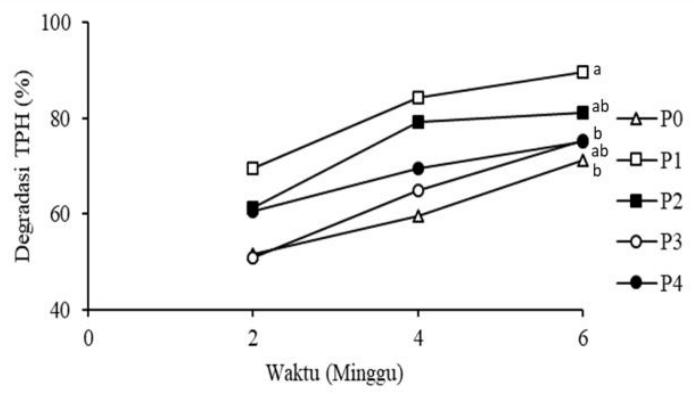

Gambar 6. Pengaruh perubahan degradasi TPH selama proses bioremediasi

Mikroorganisme pada dasarnya juga dapat menghasilkan biosurfaktan yang akan memudahkan mikrooganisme dalam mendegradasi hidrokarbon. Biosurfaktan akan diproduksi oleh mikroorganisme jika kondisi lingkungan seperti suhu dan $\mathrm{pH}$ sesuai dengan pertumbuhan mikroorganisme (Abha dan Swaranjit, 2012). Jumlah biosurfaktan yang dihasilkan oleh bakteri $P$. aeruginosa berupa rhamnolipids mungkin tidak bisa mencangkup seluruh tanah yang ada sehingga perlu adanya penambahan surfaktan dari luar. Surfaktan akan menurunkan tegangan permukaan antara hidrokarbon dengan medium, sehingga minyak akan terlepas dari matriks tanah (Benyahia dan Embaby, 2016). Penambahan surfaktan pada proses bioremediasi serta biosurfaktan yang dihasilkan bakteri, akan meningkatkan efektifitas proses biodegradasi. Hal ini sesuai dengan penelitian Urum et al. (2004) bahwa penambahan surfaktan dalam proses penghilangan kontaminasi minyak bumi lebih efektif dibandingkan dengan tanpa penambahan surfaktan, selain itu kombinasi surfaktan dan biosurfaktan akan lebih efektif dalam proses bioremediasi minyak bumi.

Berdasarkan laporan dari USEPA bahwa OSD S200 sudah digunakan dalam bioremediasi sejak tahun 1994, pada laporan tersebut OSD S200 dapat mendegradasi TPH sebesar 27,82\% selama 28 hari pengamatan (USEPA, 2017). Hasil kajian tersebut menunjukkan penggunaan OSD S200 sebagai agen bioremediasi sudah lama digunakan akan tetapi dimungkinkan kurang maksimal. Bahan yang digunakan oleh OSD S200 salah satu surfaktan utamanya yaitu LAS yang memiliki ikatan benzene didalamnya. Surfaktan yang berasal dari minyak sawit yang digunakan OSD SBRC ini memiliki kelebihan ramah lingkungan, biodegrable dan tidak toksik serta tidak menimbulkan cemaran lain. Hal ini sesuai dengan pernyataan dari Guodong et al. (2015) bahwa saat ini fokus pengembangan OSD yaitu bahan yang digunakan tidak toksik dan biodegradable.

Produksi tanaman sawit di Indonesia yang tinggi sebesar 33,5 juta ton pada tahun 2016 menunjukkan adanya potensi yang besar dalam memanfaatkan bahan yang berasal dari minyak sawit. Pemanfaatan ini ditujukan untuk meningkatkan nilai tambah dari tanaman sawit. Hasil kinerja OSD SBRC pada proses bioremediasi lebih tinggi dibandingkan dengan OSD S200. Hasil ini diperkuat hasil analisis karakteristik fisika-kimia dari OSD (Tabel 2).

Berdasarkan karakteristik fisika kimia dari kedua OSD yang digunakan menunjukkan OSD SBRC memiliki tegangan permukaan lebih rendah dibandingkan dengan OSD S200. Tegangan permukaan merupakan jumlah energi yang dibutuhkan dalam meningkatkan luas permukaan. Semakin rendah tegangan permukaan maka energi yang dibutuhkan untuk menurunkan tegangan permukaan antara minyak dan air semakin rendah. Hal ini mengindikasikan bahwa kemampuan OSD SBRC dalam melarutkan hidrokarbon lebih baik jika dibandingkan OSD S200. Menurut Charlena (2010) menyatakan bahwa meningkatnya kelarutan hidrokarbon akan meningkatkan kinerja bakteri dalam mendegradasi hidrokarbon, sehingga proses bioremediasi dapat maksimal.

Tabel 2. Perbandingan bahan baku dan sifat fisik kimia OSD SBRC dan OSD S200

\begin{tabular}{lll}
\hline \multicolumn{1}{c}{ Faktor } & \multicolumn{1}{c}{ OSD SBRC } & \multicolumn{1}{c}{ OSD S200 } \\
\hline Surfaktan & LAS $60 \%$ sebesar $8 \%$ & DEA sebesar $1,5 \%$ \\
& & MES sebesar $0,9 \%$ \\
Densitas $\left(30^{\circ} \mathrm{C}\right)$ & $0,9957 \mathrm{~g} / \mathrm{cm}^{3}$ & $0,9993 \mathrm{~g} / \mathrm{cm}^{3}$ \\
Viskositas & $1,17 \mathrm{cP}$ & $3,6 \mathrm{cP}$ \\
Tegangan Permukaan & $23,57 \mathrm{dyne} / \mathrm{cm}$ & 29,28 dyne $/ \mathrm{cm}$ \\
\hline
\end{tabular}




\section{KESIMPULAN DAN SARAN}

\section{Kesimpulan}

Berdasarkan hasil penelitian dapat disimpulkan bahwa Proses bioremediasi dengan penambahan OSD SBRD menunjukkan kinerja lebih baik dibandingkan OSD S200 dalam mendegradasi hidrokarbon. Hasil kinerja dapat diketahui dari hasil nilai TPH dan TPC. Hasil nilai TPH pada perlakuan OSD SBRC masing-masing sebesar $89,62 \%$ dan $81,11 \%$, sedangkan perlakuan OSD S200 sebesar $75,29 \%$ dan $75,09 \%$. Hasil nilai TPH tertinggi pada penelitian ini yaitu pada perlakuan OSD SBRC DOR (0,5:1). Hasil populasi bakteri pada perlakuan OSD S200 mengalami penghambatan pada awal aplikasi, sehingga menghambat proses bioremediasi.

\section{Saran}

Penelitian yang dilakukan ini masih pada tahap aplikasi pada laboratorium. Penelitian selanjutnya pada skala pilot perlu dilakukan sebelum nantinya diaplikasikan di lapangan.

\section{UCAPAN TERIMA KASIH}

Penulis mengucapkan terima kasih atas masukan yang diberikan oleh reviewer dan dewan editor untuk meningkatkan isi dari naskah ini. Penelitian ini didukung oleh Insentif Riset Sistem Inovasi Nasional (INSINAS) Kemenristekdikti Indonesia, pada nomor 1965/IT3.11/PN/2017.

\section{DAFTAR PUSTAKA}

Abha S dan Swaranjit CS. 2012. Hydrocarbon pollution: effects on living organisms, remediation of contaminated environments, and effects of heavy metals cocontamination on bioremediation. Di dalam Romero-Zerón L (Ed), Bioremediation of Crude Oil Contaminated Soil by PetroleumDegrading Active Bacteria. InTech Press. P185-206.

Adams GO, Fufeyin PT, Okoro SE, Ehinomen I. 2015. Bioremediation, biostimulation and bioaugmention: a review. International Journal Evironmetal Bioremediation and Biodegradation. 3 (1): 28-39.

Adlina S, Yani M, dan Hambali E. 2017. Oil spill dispersant (OSD) formulation of palm oil base surfactant for bioremediation of soil contaminated hydrocarbons. Chemical and Process Engineering Research. 53: 1-12.

Allen CCR, Boyd DR, Hempenstall F, Larkin MJ, Sarma ND. 1999. Contrasting effect of a nonionic surfactan on the biotransformation of polysiclic aromatic hydrocarbons to cisdihydrodiols by soil bacterial. Appl. Environ. Microbiol. Applied and
Enviromental Microbiology. 65 (3): 13351339.

Benyahia F dan Embaby AS. 2016. Bioremediation of crude oil contaminated desert soil: effect of biostimulation, bioaugmentation and bioavailability in biopile treatment system. International Journal Environmental Research Public Health. 13 (219): 1-11.

Budiawan, Fatisa Y, Khairani N. 2009. Optimasi biodegradabilitas dan uji toksisitas hasil degradasi surfaktan linear alkilbenzena sulfonat (las) sebagai bahan deterjen pembersih. Makara Sains. 13 (2): 125-133.

Charlena, Sjahrizal A, dan Roni. 2011. Profil Kelarutan Limbah Minyak Bumi dalam Air dengan Penambahan Surfaktan Anionik dan Laju Pengadukan. Seminar Nasional Kimia Terapan Indonesia 2011. (Gedung Graha Widya Bhakti, Puspiptek Serpong (ID), 24 Mei 2011.

Charlena. 2010. Bioremediasi tanah tercemar limbah minyak berat menggunakan konsorsium bakteri [Disertasi]. Institut Pertanian Bogor. Bogor (ID).

Cueva SG, Rodriguez CH, Cruz NOS, Contreras JAR, Miranda JL. 2016. Changes in bacterial populations during bioremediation of soil contaminated with petroleum hydrocarbons. Water Air Soil Pollut. 227 (91): 1-12.

Guodong Q, Yupeng Z, Xuhe R, Jie C. 2015. Research on development and effectiveness evaluation technology of new environmentfriendly oil spill dispersant. Aquatic Procedia. 3: 245-253.

Helmy Q, Laksmono R, dan Kardena E. 2015. Bioremediation of aged petroleum oil contaminated soil: from laboratory scale to full scale aplication. Procedia Chemistry. 2015 (14): 326-333.

[Kemen LH] Kementerian Negara Lingkungan Hidup. 2003. Keputuhan Menteri Lingkungan Hidup No 128 tahun 2003 Tentang Tatacara dan Persyaratan Teknis Pengolahan Limbah Minyak Bumi dan Tanah Terkontaminasi Limbah Minyak Bumi Secara Biologis. Jakarta (ID): Kementrian Negara Lingkungan Hidup.

Khalilova HK. 2015. The impact of oil contamination on soil ecosystem. Biological and Chemical Research. 2015. 133-139.

Kumar M dan Philip L. 2006. Bioremediation of endosulfan contaminated soil and waterOptimization of operating conditions in laboratory scale reactors. Journal of Hazardous Materials. 136: 354-364.

Lumbanraja P. 2014. Matakuliah Pengelolaan Limbah dan Bioremediasi: Mikroorganisme 
dalam Bioremediasi. Universitas Sumatra Utara. Medan (ID).

Mulligan CN, Yong RN, dan Gibbs BF. 2001. Surfactant-enhanced remediation of contaminated soil: a review. Engineering Geology. 2001 (60): 371-380.

Murado MA, Miron J, Gonzalez MP, Vazquez JA, Cabo ML and Pintado J. 2004. Prestige oil spill. Results of bioremediation assays on supratidal roks of salvora island (galice, spain). Consejo Superior de Investigaciones Cientifas.

Pawar RM. 2015. The effect of soil $\mathrm{pH}$ on bioremediation of polycyclic aromatic hydrocarbons (PAHS). Journal Bioremediation and Biodegradation. 3(6): 1-14.

Putri MD, Ali F, dan Zulkifliani. 2013. Bioremediasi tanah yang terkontaminasi minyak bumi dengan metode bioventing terhadap penurunan kadar total petroleum hidrokarbon dan BTEX. Universitas Indonesia (ID).

Ravindra S, Pushpendra S, dan Sharma R. 2014. Microorganism as a tool of bioremediation technology for cleaning environment: A review. Proceedings of the International Academy of Ecology and Environmental Sciences. 4 (1): 1-6.

Retno DL dan Mulyana N. 2013. Bioremediasi lahan tercemar limbah lumpur minyak menggunakan campuran bulking agents yang diperkaya konsorsia mikroba berbasis kompos iradiasi. Jurnal Ilmiah Aplikasi Isotop dan Radiasi: A Scientific Journal for The Applications of Isotopes and Radiation. 2 (9): 139-150.
Sari GL, Mizwar A, dan Trihadiningrum Y. 2015. Potensi co-composting untuk bioremediasi tanah terkontaminasi polycyclic aromatic hydrocarbon (PAH). Prosiding Seminar Nasional Manajemen Teknologi XXII. Surabaya, 24 Januari 2015.

Thapa B. Kumar AKC, dan Ghimire A. 2012. A review on bioremediation of petroleum hydrocarbon contaminants in soil. Kathmandu University Journal of Science, Engineering and Technology. 1 (8): 164170.

Urum K, Pekdemir T, dan Çopur M. 2004. Surfactants treatment of crude oil contaminated soils. Journal of Colloid and Interface Science. 276:456-464.

[USEPA] United Sates Environmental Protection Agency. 1998. Method 1664, Revision A: N-Hexane Extractable Material (HEM; Oil and Grease) and Silica Gel Treated NHexane Extractable Material (SGTHEM; Non-polar Material) by Extraction and Gravimetry. Washington (DC). USEPA Press.

US EPA. 2017. Guide to using the ncp subpart product schedule technical notebook. Washington (DC). USEPA Press.

Vidali M. 2001. Bioremediation. An overview. Pure and Applied Chemistry. 73 (7):1163-1172

Yadav BK dan Hassanizadeh SM. 2011. An overview of biodegradation of lnapls in coastal (semi)-arid environment. Water Air Soil Pollut. 220:225-239.

Zhang G, Yue-ting W, Xin-ping Q, Qin M. 2005. Biodegradation of crude oil by Pseudomonas aeruginosa in the presence of rhamnolipids. Journal of Zhejiang University Science. 6B (8): 725-73. 